\title{
Chemical Composition of Indomysis nybini from Three Stations in Basrah City, Iraq
}

\author{
Khalaf, T A, Al- Khafaji K K and Abd Al-Lateef N M* \\ Department of Marine Biology, University of Basrah, Iraq
}

Submission: October 30, 2017; Published: December 22, 2017

*Corresponding author: Nada Moffed Abd Al-Lateef, Marine Biology Department, Marine Science Centre, University of Basrah, Basrah, Iraq, Email: khaledalkhafaji70@gmail.com

\begin{abstract}
The current study was aimed to establish the nutritional status of Indomysis nybini from three stations in Basrah city, Iraq. The specimens of I. nybini were collected during the first months from 2016. The study concentrated on the nutritional status of I. nybini dry matter basis. The average values of the moisture, proteins, carbohydrates, lipids and ash were recorded for specimens I. nybini three stations.

The results of proximate composition shows that the percentage of protein in specimens of the station (1) was higher (45.04\%) than that of station (2) and (3) were reported (41.32, $39.78 \%$ ), respectively. Likewise the carbohydrate content in specimens of St. (1) was higher (9.34\%) than the (St. 2) and (St. 3) (7.56,6.67\%), respectively. The highest amount of lipid was found specimens of (St. 3), the value being9.8\% where as in the higher level of moisture content was noticed in $87.81 \%$ in specimens of (St. 1). While the lower percentage of ash in specimens of St. (1) (23.09\%) followed by (St. 2) $24.59 \%$ and then the (St. 3) where the higher recorded (25.55\%) of ash was noticed.

Biochemical analysis of adult males, ovigerious females and non-ovigerious females found high rates of protein in adult males and carbohydrate ratios were highest in non-ovigerous females, whereas fat was highest in ovigerous females.

The objective of this study for determines the proximate Chemical Composition of Indomysis nybiniis a good source of proteins and metabolically energy and average mineral supply.
\end{abstract}

Keywords: Indomysis nybini ; Proximate composition Basrah city; Iraq

\section{Introduction}

Mysid shrimps (Crustacea: Mysidae) are major organisms, inhabiting a wide range of oceanic zones, from littoral to meso- and bathypelagic. They are an important partin coastal ecosystems [1,2]. They occur in high numbers, and their ecological importance, particularly their role in food chains, feeding on detritus, phytoplankton, and zooplankton [3]. In turn, they serve as prey food for other marine organisms such as fish and invertebrates [4], thus providing a tropic link between primary producers and secondary consumers.

Mysids are used both as live and frozen food for aquarium and for aquaculture. Mysid culture has been made using various culture system and diets [4,5]. They are used as food for juvenile shrimp [6]. My sides are also considered as excellent experimental estuarine organisms for toxicity testing $[7,8]$. The chemical composition of my sides has been investigated in recent years but centres on relatively few species. The genus Indomysis , Which includes many shallow- water, estuarine and so readily accessible species.

Biju \& Panampunnayil [9] were collected the samples of my sides from salt pans in Bombay India and classified them and studied their distribution and environment. They identified a new species of Indomysis nybini for its differentiation of Indomysis annandalei through the presence of the dorsal string in the oblong matrix and its loss to the joint on the outer branch For the fourth swimming pool of male and the presence of a fork on the internal branch of the tail of the tail relative to the balance member was calculated population density of this species in these saline ponds, also observed the biochemical components of males and mature females, which showed high protein components, High carbohydrate components and female bearing brooding have a high fat ratio.

Johannsson et al. [10] were studied and investigated protein and nucleic acid concentrations and ratios in juvenile (8.5 to $12 \mathrm{~mm}$ total body length, 7 to $20 \mathrm{mg}$ wet weight (wet wt)) and young adult (12 to $14 \mathrm{~mm}, 20$ to $30 \mathrm{mg}$ wet wt) Mysisrelicta as a function of growth rate, temperature, body mass and molt stage. These relationships can then be used to assess the condition or growth rates of $M$. relictain the field. Under ad libitum feeding conditions, size and temperature should be the dominant factors determining growth rate. 


\section{Materials and Methods}

\section{Analysis of proximate composition}

The samples of Indomysis nybini were subjected to analysis the biochemical composition such as, moisture, crude protein, carbohydrate, lipid (fat) and ash of the females, males, ovigerious females, non-ovigerious females taken from the three stations:

I. Al-Faw station (pond south Al-Faw city).

II. Al-Faw station (pond in medium Al-Faw city)

III. Shatt Al-Basrah station (near Mohamed al-chasm bridge) during the first month of the 2016 on the basis of the dry weight. All analysis was carried out in triplicates.

Humidity: The percentage humidity is estimated using the drying oven at $105^{\circ} \mathrm{C}$ until the weight is stable according to the method mentioned (A.O.A.C, 2002).

Protein: Nitrogen was estimated by semi-micro kjeldahl method as described in Pearson (1970) and by protein by multiplying the value of $\mathrm{N} \times 6.25$.

Fat: Fat according to the method mentioned in A.O.A.C, (2002) using Soxhelt Soxelt.

Ash: Ash was calculated by burning samples in the Muffle furnace at a temperature of $550{ }^{\circ} \mathrm{C}$ according to the method listed in A.O.A.C, (2002).

Carbohydrates: Carbohydrates were calculated using the following formula:

Table 1: Chemical content in specimens of I. nybini in three station.
Carbohydrates $(\%)=100 \%$ - Moisture + Protein + Fat $\%+$ Ash\%

\section{Statistical analysis}

The statistical interpretation of the tabulated data was performed by using SPSS (21.0 version) for the mean standard deviation at $5 \%$ level of significanc

\section{Results}

The proximate chemical composition for specimens I. nybini, as in dry matter basis in three stations was represented in (Table 1 ), the current study were showed a higher in the proportion of protein in specimens of $I$. nybini in the first station compared to the second and third stations, with values recorded as 45.04 , 41.32 and $39.78 \%$, respectively. The carbohydrate content was 9.34\% in the I. nybini the (St. 1) which higher compared to the specimens content in $(\mathrm{St} .2,3)$ that were values recorded as 8.56 , $6.67 \%$, respectively.

The moisture content in (Table 1), indicate a higher the moisture content in the first station was $87.81 \%$ compared to the second and third stations which were 80.05 and $77.83 \%$, respectively. While the fat (lipids) content was $20.67 \%$ in the specimens of I. nybini exhibited in (St.1), which lower compared to specimens in (St. 2,3) were recorded as $21.13 \%$ and $21.50 \%$, respectively. The ash content was 24.09 in specimens in St. (1) which less compared to specimens in (St. 2,3) were recorded as $(24.59,25.55)$, respectively.

\begin{tabular}{|c|c|c|c|c|c|}
\hline Station & Protein \% & Carbohydrate \% & Carbohydrate \% & Fat \% & Ash \% \\
\hline St. 1 & 45.04 & 9.34 & 9.34 & 20.67 & 23.09 \\
\hline St. 2 & 41.32 & 7.56 & 7.56 & 21.13 & 24.59 \\
\hline St. 3 & 39.78 & 6.67 & 6.67 & 21.5 & 25.55 \\
\hline
\end{tabular}

Results of chemical analysis based on dry weight in individual from three stations

In (Tables 2-4) Comparison in biochemical content between males, non-ovigerious females and ovigerious females of I. nybini shows that high level of protein, were reported in the males and non-ovigerious females in three stations of current study. High level of lipid and moisture content were reported in the males and ovigerious females. Likewise higher level of carbohydrate and ash content was noticed in males and higher moisture was in the non-ovigerious females.

Table 2: Chemical content in specimens of $I$. nybini in station 1.

\begin{tabular}{|c|c|c|c|c|c|}
\hline Type & Humidity \% & Protein \% & Fat \% & Ash \% & Carbohydrate \% \\
\hline Males & 87.26 & 33.01 & 23.67 & 31.09 & 11.16 \\
\hline Ovigerious females & 76.29 & 25.21 & 25.13 & 2559 & 9.87 \\
\hline Non-ovigerious females & 79.3 & 48.02 & 25.5 & 21.5531 & 7.89 \\
\hline
\end{tabular}

Table 3: Chemical content in specimens of I. nybini in station 2.

\begin{tabular}{|c|c|c|c|c|c|}
\hline Type & Humidity \% & Protein \% & Fat \% & Ash \% & Carbohydrate \% \\
\hline Males & 87.81 & 35.26 & 12.97 & 27.06 & 14.87 \\
\hline Ovigerious Females & 70.05 & 33.32 & 17.23 & 22.59 & 13.12 \\
\hline Non-Ovigerious Females & 83.83 & 49.2 & 18.1 & 21.73 & 10.66 \\
\hline
\end{tabular}


Table 4: Chemical content in specimens of $I$. nybini in station 3.

\begin{tabular}{|c|c|c|c|c|}
\hline Type & Humidity \% & Protein \% & Fat \% & Carbohydrate \% \\
\hline Males & 83.0453 & 45.1002 & 12.8166 & 38.1569 \\
\hline Ovigerious females & 75.03 & 38.2 & 16.02 & 25.58 \\
\hline Non-ovigerious females & 82.86 & 53.19 & 19.98 & 29.98 \\
\hline
\end{tabular}

\section{Discussion}

The results of proximate analysis (Table 1) of Mysids are closely similar to analogous data on euphausiids. Dry body weight approximates closely to $20 \%$ of the body wet weight with the exception of an adult female. This is a broad generalization drawn from moderately variable data. Ash, chitin and the low values for carbohydrate are as expected (Table 1) from analyses of comparable organisms. The ash content represents about 1.5$2.5 \%$ of the wet weight and consequently about $7.5-12.5 \%$ of the dry weight. Determined $8.3 \%$ of the body dry weight of a Neomysis japonica, Tracy and Vallentyne (1969) state that the freshwater Mysis relicta contains $21 \%$ ash $14.6 \%$ lipids on a dry weight basis.

Small sexual differences in body composition were demonstrated in Taphromysis bowmani; males have significantly more protein and ash and significantly less chitin than females but there are no differences between the carbohydrate and lipid contents [10]. The results of the chemical analysis of specimens of this specie showed differences in the percentages of the biochemical components among males, non-ovigerious females and ovigerious females. For males and females in general, there was a relationship between the percentage of chemical components and gender, whether male or female, and the nature of environmental conditions,

A. Wide range of salinity as well as the quality of food on which it feeds. There is also a relationship between the percentages of the chemical components of the ovigerious and non-ovigerious females with the requirements of reproduction through the formation of incubation and reproduction and the production of eggs.

\section{B. High fat and protein.}

As the proportion of protein was the highest in males because it is an important component of the body, which is present for all stages of life and was the lowest in the ovigerious females, while the proportion of fat was the highest in the ovigerious females, while the proportion of carbohydrates was the highest in adult males and females and was the lowest in the ovigerious females as shown in Table 4. This is confirmed by Biju et al. [9] in his analysis of species Rhopalophthal musindicus and Biju et al. [11] of the species Mesopodopsis oriental is and Sultana et al. [12] of species Indomysis annandalei [13-15].

\section{References}

1. Azeiteiro UMM, Marques JC (1999) Temporal and spatial structure in the suprabenthic community of a shallow estuary (western Portugal: Mondego river estuary). Acta Oecol 20: 333-342.
2. Munilla T, CS Vicente (2005) Suprabenthic biodiversity of Catalan beaches (NW Mediterranean). Acta Oecol 27: 81-91.

3. Kouassi E, Pagano M, Saint JL, Sorbe JC (2006) Diel vertical migrations and feeding behavior of the mysid Rhopalophthalmus africana (Crustacea: Mysidacea) in a tropical lagoon (Ebrié, Côte dIvoire). Estuar Coast Shelf Sci 67: 355-368.

4. Domingues PM, Turk PE, Andrade JP (1999) Culture of the mysid, Mysidopsis almyra (Bowman) Crustacea: Mysidacea) in a static water system: effects of density and temperature on production, survival and growth. Aquaculture Res 30: 1-9.

5. Domingues PM, Fores R, Turk PE (2000) Mysid culture- lowering costs with alternate diets. Aquaculture Res 31(8-9): 719-728.

6. Reddy SR, Shakuntala K (1986) Use of mysids as food for culture of juvenile Penaeus merguiensis. Biology of Benthic Marine Organisms: Techniques and methods applied to the Indian Ocean. In: Mary FT (Ed.), Oxford and IBH Publishing Co., New Delhi, India, pp. 359-364.

7. Khan A, Joseph B, Khan S (1992) A new short-term mysid toxicity test using sexual maturity as an endpoint. Aquatic Toxicology 23: 97-105.

8. Kuhn A, Munns WR, Poucher S, Denise C, Suzzane L (2000) Prediction of population-level response from mysid toxicity test data using population modeling techniques. Environmental Toxicol Chem 19(9): 2364-2371.

9. Biju A, Panampunnayil US (2010) Seasonality, reproductive biology and ecology of Mesopodopsis zeylanica (Crustacea: Mysida) from a tropical estuary (Cochin backwater) in India. Plankt Benthos Res 5(2): 49-55.

10. Johannsson OE, Bowen KL, Wood CM, Smith RW, Christine CC, et al. (2008) Relating nucleic acid and protein indices to growth in Mysis relicta: ration, cycling temperature, and metabolism. Aquat Biol 4: 3346.

11. Biju A, Gireesh R, Jayalakshmi KJ, Haridevi CK, Panampunnayil SU (2009) Seasonal abundance, ecology, reproductive biology and biochemical composition of Mesopodopsis orientalis W.M. Tattersall (Mysida) from a tropical estuary (Cochin backwater) in India. Crustaceana 82(8): 981-996.

12. Sultana RQ, Kazmi B, Nasir F, Amir M, Ali W, et al. (2012) Indomysis annandalei W. Tattersall, 1914 (MYSIDACEA: MYSIDAE) from Pakistan Coastal Waters - Extremely Eurythermal and Euryhaline Opossum Shrimp. Marine Ecological J 10(3): 57-66.

13. Nimmo DR, Hamaker TL (1982) Mysids in toxicity testing-a review. Hydrobiologia 93(1-2): 171-178.

14. Beyst B, Buysse D, Dewicke A, Mees J (2001) Surf zone hyperbenthos of Belgian sandy beaches: seasonal patterns. Estuar Coast Shelf Sci 53(6): 877-895.

15. Biju A, Panampunnayil US (2011) Population structure and reproductive biology of Mesopodopsis orientalis (Crustacea: Mysida) in a tropical mangrove ecosystem in India. Mar Biodiver Rec 4(e43): 9. 


\section{Your next submission with Juniper Publishers} will reach you the below assets

- Quality Editorial service

- Swift Peer Review

- Reprints availability

- E-prints Service

- Manuscript Podcast for convenient understanding

- Global attainment for your research

- Manuscript accessibility in different formats

( Pdf, E-pub, Full Text, Audio)

- Unceasing customer service

Track the below URL for one-step submission https://juniperpublishers.com/online-submission.php 